\title{
Korean corporate culture and its transformation in the era of pandemic
}

\author{
Evgeniia Kolodina ${ }^{1}$, Irina Pashkova $^{1 *}$, and Darima Tsydenova $^{2}$ \\ ${ }^{1}$ Irkutsk State University, International Institute of Economics and Linguistics, 6 Ulan-Batorskaya Street, Irkutsk 664082, Russia \\ ${ }^{2}$ Buryat State University, Department of Far East Countries Philology, 4 Ranzhurova Street, Ulan-Ude, Republic of Buryatia 670000, \\ Russia
}

\begin{abstract}
The article deals with the concept of corporate culture and methods of its formation in the Republic of Korea. This country has been the object of growing international interest among scholars and practitioners due to its remarkable economic achievement in the last few decades. The traditional business culture of Korea is analyzed in terms of its transformation due to rapidly changing socio-economic conditions. The paper looks into the current situation affected by COVID-19 crisis. This research has been carried out within the grant agreement "Establishment of the Center for Korean Studies at Irkutsk State University" with the support of the Korea International Exchange Foundation (KF-2021).
\end{abstract}

\section{Introduction}

Corporate culture being a system of values, traditions, rules and regulations makes the basis of a company's operating model. It has been the subject of considerable academic interest in various fields such as economics, sociology, intercultural communication for the last decades.

Many researchers have explained South Korean economic success until relatively recently referring to a peculiar management model and corporate culture.

Georgy D. Toloraya, the East Asia section Director at the Institute of Economics of the Russian Academy of Sciences, visiting professor at the Moscow State Institute of International Relations (MGIMO), remarks that "Koreans are very hard-working and South Korea's economic miracle is related to selfless and intense work of several generations of Koreans. These traits have become Koreans' flesh and blood, their ethical code" [1].

The $21^{\text {st }}$ century has become the period of considerable changes in the South Korea's administrative and corporate culture related mainly to rethinking of many traditional practices [2, p. 85] that are now the main part of Korean working life.

Corporate culture is viewed in hand with national culture, their correlation can be analyzed with the help of Geert Hofstede's model "cultural programming". It gives an opportunity to track the changes in a particular system [3, p. 7-8]. According to this model, culture consists of a core and outer layers (symbols, heroes, rituals). The core is values being a stable cultural element which changes quite slowly. These values are a basic understanding that

Corresponding author: ipashkovairk@yandex.ru concerns fundamental aspects of life acquired in the course of socialization. Symbols, heroes and rituals form the outer layers. They all have a set of practices, change and transform rapidly. International cooperation can affect them [4, p. 165].

A similar system is also analyzed in Edgar Schein's theory, the world's leading expert in corporate culture summing up the results of 40 year research and offering strategies for the effective implementation of cultural innovations. He identifies 3 layers of corporate culture:

- "organizational culture or working process" external form (artifacts);

- "strategy, goal, philosophy" etc. - espoused values;

- "basic underlying assumptions" [5, p. 46]. In other words, "beliefs, perceptions, ideas and emotions" are a source of values and behaviour that members of society take for granted.

Centuries-long corporate culture hierarchy means that "inequality is taken for granted, authoritarian behaviour is norms, rules and laws change depending on the fact whom they apply to. An individual's status is often based on relations and personal qualities" $[4, p$. 162]. Nowadays Korean managers are determined to change this situation.

\section{Results and discussion}

The traditional Korean culture is often associated with chaebols culture shaped under the influence of many factors including the following: "cultural heritage rooted 
in Confucianism, national character, socio-economic conditions in 1960-1980 (military dictatorship), corporation founders' leadership and Japanese influence on personnel management" [6, p. 264].

The core components of traditional Korean corporate culture are:

- emotional harmony (기분);

- hierarchy (based on Confucian vertical system of interpersonal relations according to age, social status and gender);

- collectivism (revealed more often in one group, selfishness and individualism are shown to other groups).

Thus, corporate culture has been formed on the basis of national culture that main features are "hierarchy, paternalism, maintaining harmony in a team and competition with the outside world, results-oriented approach, progress, high productivity" [ibid]. K.V. Asmolov remarks that such culture exists in traditional Confucian society and in the conditions to strengthen economic recovery from the crisis $[4$, p. 130].

However, in the current fast-changing environment Korean companies increase their efforts to reform their rigid hierarchical corporate culture. They reject conservatism by optimizing accountability mechanisms and eliminating complex bureaucratic procedures. It is considered to be a necessary step for rapidly changing business conditions. The traditional model is becoming ineffective, it cannot any longer respond quickly to nonstandard situations that have been intensified by the COVID-19 pandemic.

There have been considerable changes in corporate culture for the last decade. A new generation has grown up, it does not share values of the older generation and it is more open to western influence. This new generation speaks out their mind, expresses dissatisfaction with the rigid management model, working overtime, long and unproductive meetings, unfair assessment of their productivity, gender equalities.

Therefore, South Korean companies are to meet specific targets, eliminate the above-mentioned negative factors and bring innovative ideas to be more competitive.

They take the following measures:

1) Carrying out a reform to eliminate functional titles (직급 호칭).

It is impossible to transform a company culture without changing the previous system with its rewarding mechanism and promotions. Moreover, specific features of enterprises should be taken into account: rigidity is typical of heavy industries, while IT industry and media companies are more progressive, open and have a simplified reporting structure.
2) Implementing horizontal communication, free exchange of information and quick decisions.

Lotte Corporation tries to change a centuries-long hierarchical management structure by creating a horizontal communication environment (수평적) 커뮤니케이션 환경). Junior Board has been initiated to improve corporate culture (주니어보드). It consists of about 5 employees chosen from 40 branches to communicate with the general manager. Junior Board is an independent body. Lotte Corporation established departments called Changes Agency in all its branches (체인지 에이전트), their activity is aimed at updating corporate culture [8]. Large banks also consider changing a corporate environment necessary. This trend is remarkable since the financial sphere has been thought to be less sensitive to changes because an incomeearning structure was stable and simple. As a result, bank employees are less risk-taking. At present many banks try to make changes empowering team leaders, reducing the powers of unit and department managers.

3) Shifting to a performance-based incentive plan.

Most organizations that focus on employee development use the 360-degree tool to assess performance and potential of their staff and enable employees to map their career path. 360 degree respondents for an employee can be his/her peers, managers (i.e. superior), subordinates, team members, customers - anyone who comes into contact with the employee and can provide valuable insight, information or feedback regarding the "on-the-job" performance of the employee. However, its implementation can be difficult due to some peculiarities of the Korean culture. Thus, Koreans try to develop and use their own tools to assess employees' performance.

4) Reducing working hours.

The National Assembly of the Republic of Korea has adopted the law of a reduced working week from 68 till 52 hours. For instance, SK Telecom banned their employees to work more than 80 hours during two weeks, SinSegae introduced 35 hours working week. A special signal or an employee informs about closing of business in many enterprises (Seoul Metropolitan City, Lotte Corporation). There is also an automatic computer system shutdown. However, in K.V. Asmolov's opinion "the experiment concerning the implementation of an automatic computer system shutdown in Seoul Metropolitan City seems more like a publicity stunt" [1].

5) Reducing the number of unnecessary meeting and limiting their time. Decline in reporting.

KB Kookmin Bank has modernized its internal reporting system since the end of last year allowing even 
entry level staff to report directly to their department's head without reporting to group leaders [9].

6) Combating corporate dinners (회식).

They were initially organized to promote informal communication among employees and encourage team spirit. However, today they are often compulsory, drawn-out and costly. Companies offer to replace them with team building events such as sport competitions, going to the theater or a concert hall.

Pandemic has made changes into this part of corporate culture. The South Korean government has released detailed advice (the 68-page document) [10]. It gives tips for both employees and employers on reducing the chances of spreading germs around their working environment. This 68-page document gives instructions about organizing different social activities. In our research devoted to the Korean corporate culture and its transformation, special attention is paid to the recommendations for work. The most important, sometimes even ruining traditional business culture "complex multidimensional process of establishing and developing contacts between people in the professional environment" [11, p. 205] are the following:

- Proactive use of flexible work hours (such as work from home or commuting during off-peak hours) and paid time off such as sick days, vacation time, and family leave. Proactive behaviour at work means self-initiated, anticipatory action aimed at changing either the situation or oneself in organizational behavior, occupational and industrial psychology.

- Proactive behaviour is acting in advance of a future situation, rather than reacting.

- Proactive behaviour is about making things happen.

- Workshops and training should be conducted online or via video conferences.

- Physical distancing in the workplace: employees sit in rows or zigzag, transparent dividers between seats.

- Creating a culture that minimizes extracurricular activities, outings, and happy hours so that people go home directly after work.

- Recommending employees to refrain from using the same common space.

- Providing makeshift meeting rooms to host visitors according to the needs of the workplace.

- Minimizing meeting attendees and maximize efficiency in order to reduce the meeting length.

\section{Conclusion}

Thus, traditional South Korean culture played an important role during the period of the country's economic growth, contributed to team spirit and labour discipline. However, new challenges and problems during pandemic lockdowns required taking measures that require a review of hierarchical and authoritarian management structures, prevailing conservatism. These measures are aimed at innovative ideas and adjustment to a rapidly changing economic, financial and social environment during the COVID-19 pandemic.

\section{References}

1. Koreans are weaned off slaving away. Available at: https://news.rambler.ru/ other/39438525-koreytsev-otuchayut-sidet-narabote-do-poteri-pulsa.

2. I.B. Stroganova. Gapjil (Korean: 갑질) as an element of the toxic South Korean corporate culture and fighting against it in the $21^{\text {st }}$ century The proceedings of the conference. 85-91 (2021).

3. G. Hofstede Culture and Organization: Software of the Mind. (London: McGrow-Hill, 1991).

4. R.K. Tangalycheva. Specific features of the RussianKorean communication in business setting. St. Petersburg State University. 2. 159-167. (2014).

5. E.H. Shine. Corporate culture innovation strategy. (2006)

6. M.N. Postrelova. Transforming corporate culture of South Korea in a new socio-economic environment The Korean peninsula in search of peace and prosperity: the proceedings of the conference. Moscow: 261-275 (2019).

7. K.V. Asmolov. Korean political culture and transformations. Moscow: Dmitry Pozharsky University. 704 (2017).

8. Lotte, 2030 employees directly suggest to the CEO activation of 'horizontal communication' corporate culture Available at: https://www.hankyung.com/economy/article/202107 1901761.

9. Korean banks speed up corporate culture reforms to survive. Lee Min-hyung Available at : https://www.koreatimes.co.kr/www/ biz/2021./02/126_303353.html.

10. A. Ossola. South Korea shows us what office life could look like after the pandemic. Available at: https://www.weforum.org/agenda/

2020/05/south-korea-office-coronavirus-covid19-workenviroment/.

11. E.A. Kolodina. Written business communication in the Republic of Korea Vestnik of Lobachevsky University of Nizhni Novgoro, 1, 205-209 (2017). 